\title{
Pengujian Potensi Jus Tomat (Lycopersicum esculentum) Sebagai Terapi Herbal Pada Tikus Rattus norvegicus Hiperkolesterolemik
}

\author{
DINA ARIBAH ${ }^{1}$, ALIF ROFIQOTUN NURUL ALIMAH ${ }^{1}$, ANINDYA NIRMALA PERMATA ${ }^{1}$, \\ BETTY LUKIATI ${ }^{1}$ \\ ${ }^{1}$ Jurusan Biologi, Fakultas Matematika dan Ilmu Pengetahuan Alam, Universitas Negeri Malang \\ J1. Semarang 5, Malang 65145 \\ email: dinaaribah021195@gmail.com
}

\begin{abstract}
Hypercholesterolemia defines as the increasing of cholesterol serum that more than the normal limit. WHO (2011) on 2008 at Indonesian said that hypercholesterolemia prevalence of woman approach about $37,2 \%$ and for man about $32,8 \%$. Tomato contain lycopene is one powerful antioxidant and can manage cholesterol metabolism with blocked the HMG-KoA enzyme reductase (enzyme for cholesterol synthesis in hepar). This study aims to determine the effect of tomato juice on the cholesterol levels in the blood of hypercholesterolemic rats and to find the effective dosis of tomato juice to decrease the cholesterol of hypercholesterolemic rats. The object of research covering 20 wistar rats (Rattus norvegicus) male 2-3 months old with 50-150g weight. The rats were divided into five groups and four replications: normal $(\mathrm{K}-)$, high-fat diet $(\mathrm{K}+)$, high-fat diet+tomato juice $200 \mathrm{mg} / 100 \mathrm{gBB}(\mathrm{P} 1)$, high-fat diet+tomato juice $400 \mathrm{mg} / 100 \mathrm{gBB}$ (P2), high-fat diet+tomato juice $800 \mathrm{mg} / 100 \mathrm{gBB}$ (P3). Tomato juice was given orally for one month every day. At the end of the treatment of rats was dissected to take blood from the heart. Data were analyzed statistically with one-way ANAVA with $\alpha=0,05$. The results showed that the tomato juice affects on the cholesterol levels of blood serum of hypercholesterolemic rats and the effective dose of tomato juice used in this study was $800 \mathrm{mg} / 100 \mathrm{gBB}$.
\end{abstract}

Keywords: cholesterol, high-fat diet, hypercholesterolemia, Rattus norvegicus, tomato

\section{INTISARI}

Hiperkolesterolemia didefinisikan sebagai meningkatnya serum kolesterol diatas batas normal. Menurut WHO (2011), pada tahun 2008 di Indonesia prevalensi hiperkolesterolemia pada wanita sebesar 37,2\% dan laki-laki sebesar 32,8\%. Tomat mengandung likopen yang merupakan salah satu antioksidan kuat dan mampu mengatur metabolisme kolesterol dengan menghambat kerja enzim HMG-KoA reduktase (enzim yang berperan dalam sintesis kolesterol di hepar). Tujuan dari penelitian ini adalah mengetahui pengaruh macam pemberian perasan tomat terhadap kadar kolesterol dalam darah pada tikus Rattus norvegicus hiperkolesterolemik dan menemukan dosis efektif perasan tomat untuk menurunkan kadar kolesterol pada tikus Rattus norvegicus hiperkolesterolemik. Sampel yang digunakan adalah 20 ekor tikus wistar Rattus norvegicus jantan umur 2-3 bulan dengan berat 50-150g. Percobaan dilakukan selama 30 hari dengan 5 perlakuan dan 4 kali ulangan; tikus normal $(\mathrm{K}-)$, diet tinggi lemak $(\mathrm{K}+)$, diet tinggi lemak + perasan tomat $200 \mathrm{mg} / 100 \mathrm{gBB}$ tikus (P1), diet tinggi lemak+perasan tomat $400 \mathrm{mg} / 100 \mathrm{gBB}$ tikus $(\mathrm{P} 2)$, diet tinggi lemak+perasan tomat $800 \mathrm{mg} / 100 \mathrm{gBB}$ tikus (P3). kadar kolesterol akan diukur setelah terapi menggunakan perasan tomat pada hari ke-31. Data yang diperoleh dianalisis menggunakan ANAVA pola satu arah berdasarkan rancangan acak lengkap (RAL), dan dilanjutkan dengan Uji BNT $0,05 \%$. Hasil penelitian menunjukkan bahwa pemberian perasan tomat dapat menurunkan kadar kolesterol pada tikus Rattus norvegicus hiperkolesterolemik dengan dosis yang paling efektif adalah $800 \mathrm{mg} / 100 \mathrm{gBB}$.

Kata Kunci: diet tinggi lemak, hiperkolesterolemik, kolesterol, Rattus norvegicus, tomat 


\section{PENDAHULUAN}

Konsumsi asam lemak jenuh dan kalori yang tinggi dapat menimbulkan kelainan metabolisme lemak yang dikenal sebagai hiperkolesterolemia yaitu meningkatnya serum kolesterol diatas batas normal. Faktor penyebab hiperkolesterolemia diantaranya obesitas, asupan makanan (tinggi kolesterol, lemak jenuh dan lemak trans), diabetes melitus, hipertiroidisme, dan sindrom nefrotik (Stapleton et al., 2010).

Menurut WHO (2011), pada tahun 2008 di Indonesia prevalensi hiperkolesterolemia pada wanita sebesar $37,2 \%$ dan laki-laki sebesar 32,8\%. Sedangkan menurut Depkes pada Riskesdas (Hasil Riset Kesehatan Dasar) tahun 2013 prevalensi hiperkolesterolemia pada laki-laki sebesar $30,0 \%$ dan pada perempuan mencapai 39,6\%.

Berdasarkan penelitian yang dilakukan Nur \& Chandra (2013) dikemukakan bahwa pemberian jus buah tomat (Lycopersicum commune) dengan kulit dan tanpa kulit berpengaruh terhadap penurunan kadar kolesterol LDL pada lansia hiperkolesterolemia. Zat gizi yang dipercaya dapat menunjang kesehatan dan mencegah penyakit hiperkolesterolemia adalah karotenoid. Salah satu karotenoid dalam makanan dan sangat dibutuhkan oleh tubuh adalah likopen. Sumber bahan makanan yang mengandung likopen salah satunya adalah tomat (Yang et al., 2011). Menurut Sumardiono et al (2007) likopen merupakan salah satu antioksidan kuat yang berperan dalam mengatur metabolisme kolesterol dengan menghambat kerja enzim HMG-KoA reduktase (enzim yang berperan dalam sintesis kolesterol di hepar) dan meningkatkan degradasi kolesterol LDL.

Berdasarkan hal tersebut, maka perlu dilakukan penelitian untuk membuktikan bahwa perasan tomat dapat mempengaruhi kandungan kolesterol pada tikus jantan putih (Rattus norvegicus) yang diberi diet tinggi lemak.

\section{METODE}

Persiapan Hewan Coba. Penelitian ini menggunakan hewan uji tikus Rattus norvegicus galur wistar jantan umur 2-3 bulan dengan berat badan 50-150 gr. Tikus yang digunakan adalah tikus yang sehat yaitu dengan memperhatikan tanda-tanda mata yang jernih, bulu yang tidak berdiri dan berat badan bertambah setiap hari. Sebelum diberi perlakuan, tikus-tikus diaklimatisasi selama satu minggu di ruangan yang memiliki pencahayaan 12 jam terang dan 12 jam gelap dengan suhu ruangan berkisar antara $23^{\circ} \mathrm{C}$ $26^{\circ} \mathrm{C}$ dengan tujuan agar hewan uji beradaptasi dengan kondisi yang akan ditempati selama percobaan. Tikus-tikus dikelompokkan dalam kandang berukuran 60 $\mathrm{cm}$ x $40 \mathrm{~cm}$ x $24 \mathrm{~cm}$ berdasarkan perlakuan yang diberikan dengan kepadatan 3-4 ekor tikus setiap kandang. Selama masa aklimatisasi, tiap kelompok tikus baik kelompok kontrol maupun kelompok perlakuan diberikan pakan dasar tikus "Pellet susu A" dan air minum yang diberikan secara ad libitum.

Persiapan Jus Tomat. Penentuan dosis diperoleh dari perhitungan hasil konversi dosis efektif manusia sebesar $150 \mathrm{gr}$ (Sudiarto dkk, 2015) dengan nilai konversi $70 \mathrm{~kg} B B$ manusia sama dengan 0,018 per 200 gr BB tikus (Laurance \& Bacharach, 1964). Jus tomat dibuat 2 hari sekali selama 30 hari setelah perlakuan tikus hiperkolesterolemik. Jus tomat dihasilkan dari buah tomat segar sebanyak 200 gram yang dicuci bersih, kemudian diiris kecil-kecil dan diblender sampai halus. Setelah itu disaring menggunakan saringan yang dilapisi dengan kassa. Hasil perasan tomat dengan konsentrasi $1000 \mathrm{mg} / \mathrm{ml}$, kemudian larutan stok diencerkan menjadi $200 \mathrm{mg} / \mathrm{ml}, 400 \mathrm{mg} / \mathrm{ml}$, dan $800 \mathrm{mg} / \mathrm{ml}$.

Persiapan Ransum Tinggi Lemak. Tikus Rattus norvegicus yang akan dijadikan kelompok kontrol positif dan kelompok perlakuan, akan diberikan ransum perlakuan agar mengalami hiperkolesterolemia. Ransum akan dibuat setiap hari selama 7 hari perlakuan pakan hiperkolesterol. Ransum tinggi lemak mengandung 15\% kolesterol dari kuning telur bebek, $10 \%$ lemak dari minyak, dan 75\% karbohidrat dari pakan Hi-Gro Medicated 551. 
Pengujian Tikus Rattus norvegicus. Penelitian ini menggunakan rancangan acak lengkap (RAL) pola satu arah dengan 5 perlakuan dan 4 ulangan. Perlakuan 1 sebagai kontrol negatif $\left(\mathrm{K}^{-}\right)$yaitu kelompok tikus yang diberi pakan standar tanpa jus tomat, perlakuan 2 sebagai kontrol positif $\left(\mathrm{K}^{+}\right)$yaitu tikus hiperkolesterolemik tanpa diberi jus buah tomat. Perlakuan 3 sebagai (P1) yaitu tikus hiperkolesterolemik yang diberi jus buah tomat dengan dosis $200 \mathrm{mg} / 100$ gram BB tikus. Perlakuan 4 sebagai perlakuan (P2) yaitu tikus hiperkolesterolemik yang diberi jus buah tomat dengan dosis $400 \mathrm{mg} / 100$ gram BB tikus. Perlakuan 5 sebagai perlakuan (P3) yaitu tikus hiperkolesterolemik yang diberi jus buah tomat dengan dosis 800 $\mathrm{mg} / 100$ gram BB tikus. Setelah tikus pada tiap kelompok diaklimatisasi selama satu minggu, tikus dari kelompok kontrol positif dan kelompok perlakuan akan diberi pakan berlemak tinggi selama satu minggu berikutnya sebanyak 30 gram/hari dan air minum yang diberikan secara ad libitum. Tahap pengujian menggunakan jus tomat dilakukan selama 30 hari setelah satu minggu perlakuan hiperkolesterolemia. Pemberian jus tomat pada tikus Rattus novergicus hiperkolesterolemik dilakukan setiap hari sebanyak $1 \mathrm{ml} /$ ekor tikus secara oral gavage dengan dosis yang bervariasi, yaitu dosis 200, 400, dan $800 \mathrm{mg} / 100$ gram BB tikus.

Pengukuran Kadar Kolesterol Total. Pengukuran kadar kolesterol darah total dilakukan setelah diberi terapi jus tomat pada hari ke 31 untuk setiap tikus. Darah tikus diambil jantung dan ditampung dengan tabung sentrifus. Darah didiamkan selama 30 menit dan disentrifus selama 30 menit dengan kecepatan $3000 \mathrm{rpm}$ menggunakan sentrifus "Harmonic Series". Serum darah dipipet dengan pipet mikro sebanyak $0,01 \mu 1$ dimasukkan dalam tabung reaksi. Reagan pemeriksaan yang digunakan adalah "DiaSysCholesterol FS" secara spektrofotometrik menggunakan alat microlab 300 (Murwani $\mathrm{dkk}, 2006$ ).

Analisis data. Data diolah secara statistik dengan menggunakan Analisa Varian (ANAVA) pola satu arah berdasarkan rancangan acak lengkap (RAL), dan dilanjutkan dengan Uji BNT 0,05\%.

Uji DPPH. Pengukuran aktivitas antioksidan perasan buah tomat dilakukan dengan metode DPPH (1,1-difenil-2pikrilhidrazil). Prinsip pengujian metode DPPH adalah mereaksikan radikal bebas DPPH dengan antioksidan pada buah tomat yang dapat diukur dari perubahan warna ungu DPPH menjadi warna kuning. Sampel ekstrak dibuat dengan konsentrasi $0 \%, 20 \%, 40 \%$, $80 \%$, dan $100 \%$. Sampel diukur absorbansinya dengan panjang gelombang $517 \mathrm{~nm}$ dan metanol sebagai blangko menggunakan UV-VIS. Menurut Carrapeiro et al (2007) aktivitas antioksidan dihitung berdasarkan persentase perendaman radikal bebas DPPH oleh senyawa antioksidan dengan rumus:

\section{$\%$ Inhibisi $=$ Abs.standart - Abs.Sampel $\times 100 \%$ Abs.standart}

Keterangan:

Abs.standart: Serapan radikal DPPH pada $517 \mathrm{~nm}$ Abs.Sampel: Serapan radikal DPPH yang tersisa di dalam serum pada $517 \mathrm{~nm}$

\section{HASIL}

Rerata kadar kolesterol darah total (mg/dl) tikus Rattus norvegicus dapat dilihat pada gambar 1. Setelah data dianalisis menggunakan Analisa Varian (ANAVA) pola satu arah (tabel 1) diketahui bahwa F hitung kadar kolesterol darah total tikus (Rattus norvegicus) $>\mathrm{F}$ tabel 5\%, sehingga Ho ditolak dan hipotesis penelitian diterima, berarti macam pemberian jus tomat berpengaruh terhadap kadar kolesterol darah total pada tikus Rattus norvegicus hiperkolesterolemik.

Hasil uji lanjut menggunakan BNT $0,05 \%$ menunjukkan bahwa pemberian jus tomat dosis $800 \mathrm{mg} / 100$ gr BB tikus (P3) menghasilkan rerata kadar kolesterol darah total tikus yang paling rendah dan tidak berbeda nyata dengan pemberian jus tomat dosis $400 \mathrm{mg} / 100$ gr BB tikus (P2). Hasil pengujian aktivitas antioksidan pada perasan buah tomat disajiakan pada gambar 2 . Berdasarkan grafik diketahui bahwa aktivitas 
antioksidan paling besar pada konsentrasi 100\% sebesar 90,97\%.

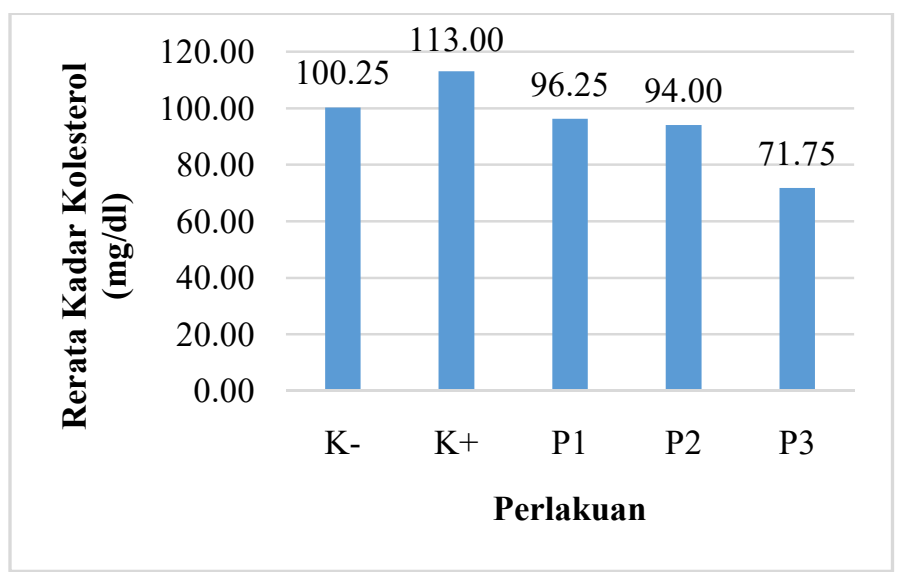

Gambar 1. Grafik rerata kadar kolesterol darah total (mg/dl) tikus Rattus norvegicus

Keterangan: $\mathrm{K}-=$ tikus normal; $\mathrm{K}+=$ tikus diet tinggi lemak; $\mathrm{P} 1=$ diet tinggi lemak+perasan tomat 200mg/100gBB tikus; $\mathrm{P} 2=$ diet tinggi lemak+perasan tomat $400 \mathrm{mg} / 100 \mathrm{gBB}$ tikus; $\mathrm{P} 3=$ diet tinggi lemak + perasan tomat $800 \mathrm{mg} / 100 \mathrm{gBB}$ tikus.

Tabel 1. Ringkasan ANAVA satu jalur

\begin{tabular}{lllllll}
\hline SK & db & JK & KT & $\mathbf{F}_{\text {hitung }}$ & & $\mathbf{F}_{\text {tabel 0,05 }}$ \\
\hline Perlakuan & 4 & 3578,7 & 894,675 & 4,063933682 & $\mathrm{~S}^{*}$ & 3,06 \\
\hline Galat & 15 & 3302,25 & 220,15 & & & \\
\hline Total & 19 & 6880,95 & & & & \\
\hline
\end{tabular}

Keterangan: S* Signifikan (berpengaruh)

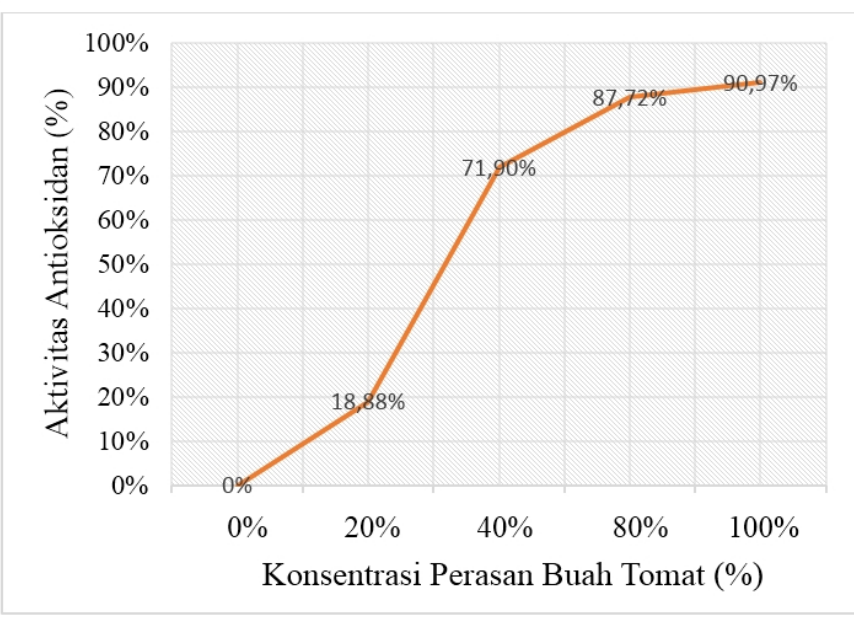

Gambar 2. Grafik aktivitas antioksidan pada perasan buah tomat

\section{PEMBAHASAN}

Mengkonsumsi makanan tinggi lemak sangat berpotensi menghasilkan radikal bebas. Menurut Droge \& Kinscherf (2008) lemak mempunyai ikatan rangkap pada atom C-nya dan sangat mudah dioksidasi dan akan membentuk radikal bebas. Antioksidan merupakan senyawa yang dapat menunda, memperlambat, dan mencegah proses oksidasi. Antioksidan mampu meredam dampak dari radikal bebas dengan cara memberikan elektronnya kepada molekul radikal bebas tanpa menganggu fungsinya dan dapat memutus reaksi berantai dari radikal bebas. Likopen merupakan senyawa antioksidan potensial yang terdapat dalam 
tomat. Likopen adalah salah satu carotenoid (Rao et al, 2007). Menurut Karppi et al (2009) likopen pada tomat dapat menghambat sintesis kolesterol dengan cara menghambat kerja enzim HMG-CoA reduktase. Sedangkan menurut Haseen et al (2009) likopen bekerja dengan cara menangkap radikal bebas superoksida $\left(\mathrm{O} 2 *_{-}\right)$sehingga membentuk ikatan yang tidak reaktif dan memutus reaksi berantai radikal bebas, sehingga mampu menurunkan risiko terjadinya berbagai penyakit seperti penyakit hiperkolesterolemia dan kardiovaskuler.

Menurut penelitian yang telah dilakukan oleh Iswari \& Susanti (2016) diketahui bahwa aktivitas antioksidan pada jus buah tomat sangat tinggi yaitu $38,35 \%$. Hasil uji aktivitas antioksidan menggunakan metode DPPH (1,1-difenil-2-pikrilhidrazil) menunjukkan pada konsentari $80 \%$ dan $100 \%$ perasan buah tomat menghasilkan aktivitas antioksidan sebesar 87,72\% dan 90,97\% (Gambar 2). Besarnya aktivitas antioksidan pada perasan buah tomat dapat mengurangi radikal bebas akibat makanan tinggi lemak.

\section{KESIMPULAN}

Pemberian perasan tomat dapat menurunkan kadar kolesterol pada tikus Rattus norvegicus hiperkolesterolemik. Dosis perasan tomat yang efektif untuk menurunkan kadar kolesterol pada tikus Rattus norvegicus hiperkolesterolemik adalah $800 \mathrm{mg} / 100 \mathrm{gr}$ BB tikus.

\section{DAFTAR PUSTAKA}

Carrapeiro MM, Donato J, Goncalves RC. 2007. Effect of Lycopene on Biomarkers of Oxidative Stress in Rats Supplemented with Omega-3 Polyunsaturated Fatty Acid. Food Research International. vol 40: 939-946.

Droge W and Kinscherf R. 2008. Aberrant Insulin Receptor Signaling and Amino Acid Homeostasis as A Major Cause of Oxidative Stress in Aging. Antioxid Redox Signal. vol 10(4): 78-661.

Haseen F, Cantwell MM, O'Sullivan JM, Murray LJ. 2009. Lycopene Supplementation and Prostate Cancer
Progression. Prostate Cancer and Prostatic Diseases. vol 12: 325-332.

Iswari RS and Susanti R. 2016. Antioxidant Activity from Various Tomato Processing. Journal of Biology \& Biology Education. vol 8 (1):127-132.

Karppi J, Kurl S, Nurmi T, Rissanen TH, Pukkala E, Nyyssönen K. 2009. Serum Lycopene and The Risk of Cancer: The Kuopio Ischaemic Heart Disease Risk Factor (KIHD) Study. Ann Epidemiol. vol 19(7): 8-512.

Murwani S, Ali M, Murliartha K. 2006. Diet Aterogenik pada Tikus Putih (Rattus norvegicus Strain Wistar) sebagai Model Hewan Aterosklerosis. Jurnal Kedokteran Brawijaya. vol XXII (1): 1-4.

Nur DM and Chandra A. 2013. The Effect of Tomato Juice Whole and Peeled (Lycopersicum commune) to Decreased Low-Density Lypoprotein Cholesterol Levels in The Elderly Hypercholesterolemia [Artikel Penelitian]. Semarang: Fakultas Kedokteran, Universitas Diponegoro.

Rao LG, Mackinnon ES, Josse RG, Murray TM, Strauss A, Rao AV. 2007. Lycopene consumption decreases oxidative stress and bone resorption markers in postmenopausal women. Osteoporosis Internasional. vol 18(1): 15-109.

Departemen Kesehatan. 2013. Riset Kesehatan Dasar (RISKESDAS). Jakarta: Badan Penelitian dan Pengembangan Kesehatan, Departemen Kesehatan.Republik Indonesia.

Stapleton PA, Goodwill AG, James ME, Brock RW, Frisbee JC. 2010. Hypercholesterolemia and Microvascular Dysfunction: Interventional Strategies. Journal of Inflamation. vol 7(54): 1-10.

Sudiarto, Soewito, Huriah T. 2015. Potensi Licopen pada Tomat Untuk Menurunkan Kadar Kolesterol (LDL) pada Penderita Hipertensi (Hiperkolesterolemia). Journal of Nursing and Health. Vol 1(1): 38-47.

Sumardiono S, Basri, Sihombing RP. 2007. Anasilis Sifat-sifat Psiko-kimia Buah Tomat (Lycopersicon esculentum) Jenis 
Tomat Apel, Guna Peningkatan Nilai Fungsi Buah Tomat sebagai Komoditi Pangan Lokal. [Skripsi]. Semarang: Jurusan Teknik Kimia, Fakultas Teknik, Universitas Diponegoro.

WHO (World Health Organization). 2011. NCD (Noncommunicable diseases) Country Profiles 2011. http://www.who.int/. Diakses tanggal 17 Juni 2016.

Yang Y, Chan SW, Hu M, Walden R, Tomlinson B. 2011. Effects of Some Common Food Constituens on Cardiovaskular Disease. Internasional Scholarly Research Network (ISRN) Cardiology. hal 1-16. 